\title{
How Aware are We of the Immune Status of Hepatitis $B$ and Hepatitis A in Chronic Hepatitis C Patients? A Multicenter Retrospective Study from Turkey
}

\author{
Kronik Hepatit C Hastalarında Hepatit B ve Hepatit A'nın Bağıșıklık Durumunun Ne \\ Kadar Farkındayız? Türkiye'den Çok Merkezli Retrospektif Bir Çalıșma
}

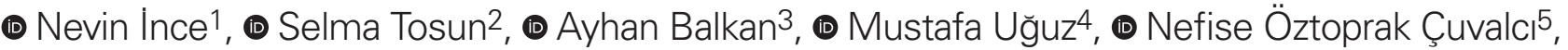

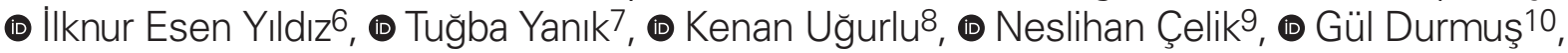

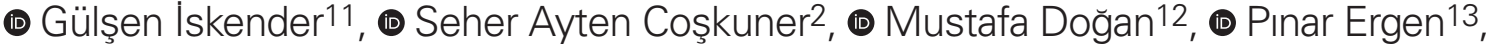 \\ (1) Ramazan Gözüküçük14, (1) Muhammed Bekçibaşı15

\begin{abstract}
'Düzce University Faculty of Medicine, Department of Infectious Diseases and Clinical Microbiology, Düzce, Turkey 2lzmir Bozyaka Training and Research Hospital, Clinic of Infectious Diseases and Clinical Microbiology, Izmir, Turkey

${ }^{3}$ Gaziantep University Faculty of Medicine, Department of Gastroenterology, Gaziantep, Turkey

${ }^{4}$ Silifke State Hospital, Clinic of Infectious Diseases and Clinical Microbiology, Mersin, Turkey

5 University of Health Sciences Turkey, Antalya Training and Research Hospital, Clinic of Infectious Diseases and Clinical Microbiology, Antalya, Turkey

${ }^{6}$ Recep Tayyip Erdoğan University Faculty of Medicine, Department of Infectious Diseases and Clinical Microbiology, Rize, Turkey

7 Sivas Numune Hospital, Clinic of Infectious Diseases and Clinical Microbiology, Sivas, Turkey

825 Aralı State Hospital, Clinic of Infectious Diseases and Clinical Microbiology, Gaziantep, Turkey

${ }^{9}$ Erzurum Regional Training and Research Hospital, Clinic of Infectious Diseases and Clinical Microbiology, Erzurum, Turkey

${ }^{10}$ Bursa Yüksek Ihtisas Training and Research Hospital, Clinic of Infectious Diseases and Clinical Microbiology, Bursa, Turkey

${ }^{11}$ Dr. Abdurrahman Yurtaslan Ankara Oncology Training and Research Hospital, Clinic of Infectious Diseases and Clinical Microbiology, Ankara, Turkey

${ }^{12}$ Çorlu State Hospital, Clinic of Infectious Diseases and Clinical Microbiology, Tekirdağ, Turkey

13/stanbul Medeniyet University, Göztepe Training and Research Hospital, Clinic of Infectious Diseases and Clinical Microbiology, Istanbul, Turkey

${ }^{14}$ Hisar Intercontinental Hospital, Clinic of Infectious Diseases and Clinical Microbiology, Istanbul, Turkey

${ }^{15}$ Diyarbakır Bismil State Hospital, Clinic of Infectious Diseases and Clinical Microbiology, Diyarbakır, Turkey
\end{abstract}

\section{ABSTRACT}

Objectives: Patients with chronic hepatitis $\mathrm{C}$ virus (HCV) infection and superinfection by hepatitis A or hepatitis B virus have higher morbidity and mortality when compared with those without HCV infection. The aim of this study was to determine hepatitis $A$ and $B$ seroprevalence rates and immunity in patients with chronic HCV in different regions of Turkey.
ÖZ

Amaç: Kronik HCV enfeksiyonu olan ve hepatit A veya hepatit $B$ virüsü ile süperenfeksiyonu olan hastalar, HCV enfeksiyonu olmayanlara göre daha yüksek morbidite ve mortaliteye sahiptir. Bu çalışmanın amacı, Türkiye'nin farkı bölgelerindeki kronik HCV hastalarında hepatit A ve B seroprevalans oranlarııı ve bağışıkliğı belirlemektir.

İnce N, Tosun S, Balkan A, Uğuz M, Öztoprak Çuvalcı N, Esen Yıldız I, Yanık T, Uğurlu K, Çelik N, Durmuş G, İsender G, Coşkuner SA, Doğan M, Ergen P, Gözüküçük R, Bekçibaşı M. How Aware are We of the Immune Status of Hepatitis B and Hepatitis A in Chronic Hepatitis C Patients? A Multicenter Retrospective Study from Turkey.. Viral Hepat J. 2020;26:131-134.

Address for Correspondence: Nevin Ince MD, Düzce University Faculty of Medicine, Department of Infectious Diseases and Clinical Microbiology, Düzce, Turkey Phone: +90 5053505839 E-mail: drnevince@gmail.com ORCID ID: orcid.org/0000-0002-0129-4536 Received: 05.08.2020 Accepted: 05.09.2020

(อ) Copyright 2020 by Viral Hepatitis Society / Viral Hepatitis Journal published by Galenos Publishing House. 


\section{ABSTRACT}

Materials and Methods: This multi-center study involving HCVinfected chronic cases was conducted between July 2016 and October 2017. Serological tests of Hepatitis B surface antigen, anti$\mathrm{HBs}$, hepatitis B core antibody (anti-HBc) immunoglobulin G (lgG) and anti-HAV IgG were evaluated by ELISA, and the files of HCV infected patients at the age of 18 or over who applied to 15 hospitals in 13 different cities of our country were screened.

Results: Three hundred sixty-two of the 828 patients were men and 466 were women. The prevalence of $\mathrm{HBV} / \mathrm{HCV}$ coinfection was $2.4 \%$, while the anti-HBs positivity rate was $46.9 \%$. Of the 610 patients evaluated in terms of anti-HAV IgG serology, $88.8 \%$ were anti-HAV IgG positive, while $11.1 \%$ were anti-HAV IgG negative. Isolated anti-HBc lgG positivity was detected in $5.8 \%$ of patients.

Conclusion: Revealing the serological status of other hepatitis agents, such as hepatitis A and B, in patients with chronic hepatitis $\mathrm{C}$ is important in terms of providing the opportunity to immunize or treat when required.

Keywords: Chronic hepatitis C, hepatitis A, hepatitis B, seroprevalence
ÖZ

Gereç ve Yöntemler: HCV ile enfekte kronik olguları içeren çok merkezli bu çalışma Temmuz 2016-Ekim 2017 tarihleri arasında yapıldı. Hepatit B yüzey antijeni ( $\mathrm{HBsAg}$, antiHBs, antiHBclgG ve antiHAVIgG'nin serolojik testleri ELISA ve 18 yașinda HCV ile enfekte hastaların dosyaları veya Ülkemizin 13 farkı ilinde 15 hastaneye bașvuranlar tarandı. Ülkemizin 13 farklı ilindeki 15 hastanenin HCV ile enfekte hastalarının dosyaları tarandı ve ELISA yöntemi ile değerlendirilen $\mathrm{HBsAg}$, anti-HBs, anti-HBc lgG ve antiHAV IgG bakıldı.

Bulgular: Sekiz yüz yirmi sekiz hastanın üç yüz altmış ikisi erkek, 466 kadındı. HBV/HCV koenfeksiyon prevalansı \%2,4 iken antiHBs pozitiflik oranı \%46,9 idi. Anti-HAV IgG serolojisi açısından değerlendirilen 610 hastanın \%88,8'i anti-HAV IgG pozitif, \%11,1'i anti-HAV IgG negatif idi. Hastaların \%5,8'inde izole anti-HBc IgG pozitifliği saptandı.

Sonuç: Kronik hepatit C'li hastalarda hepatit A ve B gibi diğer hepatit ajanlarının serolojik durumunun ortaya konması, gerektiğinde așılama veya tedavi fırsatı sağlama açısından önemlidir.

Anahtar Kelimeler: Kronik hepatit C, hepatit A, hepatit B, seroprevalans

\section{Introduction}

Hepatitis $\mathrm{C}$ virus $(\mathrm{HCV})$ infection is a global public health problem. More than 170 million people worldwide are believed to be infected with $\mathrm{HCV}$, the prevalence of which is approximately $3 \%$ $(1,2)$. In Turkey, HCV seroprevalence ranges between $0.4 \%$ and $1.15 \%$ in the general population (3). Improved understanding of the molecular biology of HCV in recent years has led to improvements in the effectiveness and tolerability of $\mathrm{HCV}$ treatment, and to the development of numerous direct-acting antiviral agents (4). Despite this success achieved in treatment, however, there is still no vaccine for the HCV. Protection against other hepatitis viruses such as hepatitis $A$ and hepatitis $B$ that cause inflammation in the liver can be provided through immunization. Of these viruses, the HAV is asymptomatic in childhood, but manifests as a self-limiting infection with mortality rates between $0.01 \%$ and $0.5 \%$ in adults (5). In addition, HAV superinfection in patients with chronic liver disease, including patients with chronic hepatitis caused by $\mathrm{HCV}$, is associated with a risk of fulminant hepatitis and associated mortality (6).

The number of people worldwide infected with chronic HBV infection, which is capable of causing cirrhosis and hepatocellular cancer by leading to liver damage, similarly to chronic hepatitis $C_{\text {, }}$ is approximately 240 million, and every year some one million people die from the disease (7). The prevalence of hepatitis B positivity in Turkey varies between regions, but generally ranges between $2 \%$ and $12 \%$ (8). Several studies have shown accelerated progression of liver fibrosis in patients with chronic $\mathrm{HCV}$ infection and co-infection with HBV, with a higher risk of hepatocellular carcinoma (HCC) compared to chronic HCV infection alone $(9,10)$. For that reason, Centers for Disease Control and Prevention and the World Health Organization Advisory Committee of Immunization Practices recommend that patients with chronic liver disease, including chronic hepatitis $\mathrm{C}$, be immunized against both HAV and HBV (11).
The aim of this study was to determine hepatitis $A$ and B seroprevalence rates and immunity in patients with chronic hepatitis $\mathrm{C}$ in different regions of Turkey.

\section{Materials and Methods}

The research was planned as a multi-center observational study. Physicians working in infectious diseases and gastroenterology clinics in 13 different provinces in Turkey between July 2016 and October 2017 were contacted. Three centers were university hospitals, seven were education-research hospitals, four were public hospitals, and one was a private hospital. The files of patients over 18 under follow-up with diagnoses of chronic hepatitis $C$ were screened retrospectively. The demographic data and HBsAg, anti$\mathrm{HBs}$, anti-HBc IgG and anti-HAV IgG results investigated using the ELISA method of 828 chronic hepatitis $C$ patients whose records were available were recorded onto an Excel file.

\section{Statistical Analysis}

Statistical analysis was performed on SPSS (Version 13.0) software. Numerical variables such as age were expressed as mean \pm standard deviation and median, while categorical data were expressed as number and percentage.

\section{Results}

Three hundred sixty-two (43.8\%) of the 828 patients were men and 466 (56.2\%) were women. The patients' mean age was $57.85 \pm 14.75$ years (18-86). The genotype rates of the hepatitis $\mathrm{C}$ patients and the names of the regions where the data were collected are shown in Table 1. The prevalence of $\mathrm{HBV} / \mathrm{HCV}$ coinfection was $2.4 \%(n=20)$, while the anti-HBs positivity rate was $46.9 \%(n=389)$. Of the 610 patients evaluated in terms of anti-HAV IgG serology, 88.8\% ( $n=542)$ were anti-HAV IgG positive, while $11.1 \%(n=68)$ were anti-HAV IgG negative. Isolated anti HBc 
IgG positivity was detected in 5.8\% ( $n=611)$ of patients (Table 2). Approximately half the HCV-positive patients $(47.8 \%, n=396)$ were anti-HBs negative. In addition, a significant proportion of the patients $(26.3 \%, n=218)$ were not examined in terms of hepatitis A serology. The proportions of patients not examined in terms of HBsAg and anti-HBs were 1.9\% $(n=16)$ and $1.8 \% \quad(n=15)$, respectively.

\section{Discussion}

The epidemiology of HAV and HBV varies depending on the geographical area involved. The situation in each country therefore needs to be examined to determine the immunological status of the population against these viruses. Knowledge of the serological profile against HAV and HBV, that can be prevented through immunization, especially in patients with underlying chronic hepatitis $\mathrm{C}$, is important in order to reduce the risk of superinfection $(9,10,11)$

Rates of anti-HAV IgG seropositivity in patients with chronic hepatitis vary considerably in studies from different countries Differing results have even been obtained among different regions of the same country. In a study from Italy, the rate of anti-HAV IgG seropositivity was $53.5 \%$ among 2830 patients with chronic hepatitis, the rate being higher in the southern and central provinces of the country than in the north (12). Anti-HAV IgG seropositivity of $55 \%$ was determined in chronic hepatitis patients in the USA, another developed country (13). Three different studies from Italy have reported anti-HAV IgG seropositivity rates of $79.3 \%$ (12) and $85.7 \%$ (14) in chronic hepatitis patients, and as high as $97.6 \%$ (15) in patients with chronic hepatitis C. This situation, associated with the higher mean age among HCV patients and increased seropositivity with age, was revealed in a study by da

\begin{tabular}{|l|l|}
\hline \multicolumn{2}{|l|}{ Table 1. HCV patients' demographic characteristics and genotype rates } \\
\hline \multicolumn{2}{|l|}{ Characteristics } \\
\hline Male/female $\mathrm{n}(\%)$ & $362(43.8) / 466$ (56.2) \\
\hline Mean age, years & $57.85 \pm 14.75$ \\
\hline Genotype (n=465) & 88 \\
\hline 1 & 336 \\
\hline $1 \mathrm{~b}$ & 12 \\
\hline 2 & 19 \\
\hline 3 & 8 \\
\hline 4 & 2 \\
\hline 5 & \\
\hline HCV: Hepatitis C virus &
\end{tabular}

\begin{tabular}{|l|l|}
\hline \multicolumn{2}{|l|}{ Table 2. HCV-positive patients' serological status } \\
\hline Serological marker & $\%$ \\
\hline Anti-HAV IgG ( $n=542 / 610)$ & $88.8 \%$ \\
\hline HBsAg ( $n=20)$ & $2.4 \%$ \\
\hline Anti-HBs ( $n=389)$ & $46.9 \%$ \\
\hline Isolated anti-HBc IgG positivity ( $n=611)$ & $5.8 \%$ \\
\hline $\begin{array}{l}\text { HCV: Hepatitis C virus, HAV: hepatitis A virus, IgG: Immunoglobulin, HBsAg: } \\
\text { Hepatitis B surface antigen, }\end{array}$ \\
\hline
\end{tabular}

Silva et al. (16). The results of the present study indicated a high prevalence (88.8\%) of anti-HAV lgG, a serological marker that

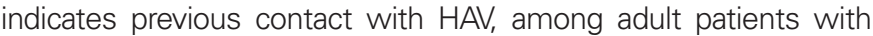
chronic HCV infection. However, we also found that the anti-HAV IgG test was not requested or the results were not known in one in four patients with chronic hepatitis C (26.3\%). This suggests that rather more care is required on the subject of serological screening among chronic hepatitis patients.

One study showing that HAV superinfection in patients with chronic HCV infection can be fatal reported that HAV superinfection developed in 17 out of 432 chronic hepatitis $\mathrm{C}$ patients followedup over seven years, and that six of these died from fulminant hepatitis (6). Another study showed low effectiveness when hepatitis A or B immunization was administered to patients who were decompensated due to chronic hepatitis or in the immunosuppressed period following liver transplantation (17). Both studies are noteworthy in showing the importance of screening of chronic hepatitis patients and of early immunization of seronegative patients in the early period.

Patients coinfected with HBV and HCV experience more rapid fibrosis, higher progression rates, and more severe liver disease. The risk of developing HCC is also higher in coinfected patients compared to those with HBV or HCV monoinfection $(18,19)$. Due to the lack of extensive research into HBV/HCV coinfection worldwide, the prevalence is not exactly known. Marot et al. (10) study from the Far East showed HBV positivity in 2-10\% of chronic hepatitis $C$ patients. A study from the USA emphasized the higher likelihood of encountering HBV in chronic hepatitis $\mathrm{C}$ due to similar modes of transmission, such as intravenous drug use, in both (20). The number of studies investigating HBV seroprevalence in patients with HCV infection in Turkey is limited. In one multi-center study from Turkey, 10,167 patients were screened, and HBV/HCV coinfection was detected in $99(974 / 100,000)(21)$. Demirtürk et al. (22) determined an HBV positivity rate of $1.9 \%$ in patients infected with chronic hepatitis $\mathrm{C}$, while Akça et al. (23) reported a figure of $4.4 \%$. Studies show that anti-HBs seropositivity in patients with chronic hepatitis C varies between $29.3 \%$ and $39.1 \%(24,25)$. According to the results of the present study, HBV/HCV coinfection $(2.4 \%)$ was similar to the rates in previous studies, while anti-HBs seropositivity (46.9\%) was higher. Isolated anti-HBc IgG positivity is common in HBsAg and anti-HBs negative cases. Although the prevalence of this serological profile varies according to societies, it is between $0.1-20 \%(26,27)$. In a study conducted by Tahmaz et al. (28) from our country, anti-HBc IgG seropositivity was found to be $12.5 \%$, and in our study it was found to be $5.8 \%$ similar to the literature.

\section{Study Limitations}

One limitation of this study is that due to its retrospective design and multicenter nature not all patients' data could be retrieved. No distinction between immunization and natural immunity was therefore possible.

\section{Conclusion}

Revealing the serological status of other hepatitis agents, such as hepatitis $A$ and $B$, in patients with chronic hepatitis $C$ is important in terms of providing the opportunity to immunize or treat when 
required. The fact that the serological profile of hepatitis $A$ virus was not examined to a significant extent in our study showed the lack of screening. Further more extensive studies are now needed to reveal the true picture in Turkey.

Conflict of Interest: No conflict of interest was declared by the author.

Financial Disclosure: The authors declared that this study received no financial support.

\section{Ethics}

Ethics Committee Approval: Retrospective study.

Informed Consent: Retrospective study.

Peer-review: Externally peer-reviewed.

\section{Authorship Contributions}

Concept: N.I., S.T., Design: S.T., Data Collection or Processing: A.B., M.U., N.Ö.Ç., I.E.Y., T.Y., K.U., N.Ç., G.D., G.I., S.A.C., M.D., Analysis or Interpretation: P.E., R.G., M.B., Literature Search: N.I., Writing: N.I., S.T.,

Conflict of Interest: The authors declare no conflict of interest.

Financial Disclosure: The authors declare that this study has not received any financial support.

\section{References}

1. Mohd Hanafiah K, Groeger, J, Flaxman AD, Wiersma ST. Global epidemiology of hepatitis C virus infection: New estimates of age-specific antibody to HCV seroprevalence. Hepatology. 2013;57:1333-1342.

2. Messina JP, Humphreys I, Flaxman A, Brown A, Cooke GS, Pybus OG, Barnes E. Global distribution and prevalence of hepatitis $C$ virus genotypes. Hepatology. 2015;61:77-87.

3. Tosun S. The Changing Viral Hepatitis Epidemiology in our Country. Ankem Derg. 2013;27:128-134.

4. Gutierrez JA, Lawitz EJ, Poordad F. Interferon-free, direct-acting antiviral therapy for chronic hepatitis C. J Viral Hepat. 2015;22:861170

5. Rowe IA, Parker R, Armstrong MJ, Houlihan DD, Mutimer DJ Hepatitis A virus vaccination in persons with hepatitis $C$ virus infection: consequences of quality measure implementation. Hepatology. 2012;56:501-506

6. Vento S, Garofano T, Renzini C, Cainelli F, Casali F, GhironziG Ferraro T, Concia E. Fulminant Hepatitis Associated with Hepatitis A Virus Superinfection in Patients With Chronic Hepatitis C. N Engl J Med. 1998;338:286-290.

7. WHO. Hepatitis B. Available from: http://www.who.int/ mediacentre/factsheets/fs204/en/

8. Tozun N, Ozdogan O, Cakaloglu Y, Idilman R, Karasu Z, Akarca U, Kaymakoglu S, Ergonul O. Seroprevalence of hepatitis B and C virus infections and risk factors in Turkey: a fieldwork TURHEP study. Clin Microbiol Infect. 2015;21:1020-1026.

9. Yoshio $S$, Kanto T. Host-virus interactions in hepatitis $B$ and hepatitis C infection. J Gastroenterol. 2016;51:409-420.

10. Marot A, Belaid A, Orlent H, Sersté T, Michielsen P, Colle I, Laleman W, de Galocsy C, Reynaert H, D'Heygere F, Moreno C, Doerig C, Henrion J, Deltenre P. Characteristics of patients with hepatitis $B$ virus and hepatitis $C$ virus dual infection in a Western European country: Comparison with monoinfected patients. Clin Res Hepatol Gastroenterol. 2017;41:656-663

11. Reiss G, Keeffe EB. Review article: hepatitis vaccination inpatients with chronic liver disease. Aliment Pharmacol Ther. 2004:19:715727.
12. Sagnelli E, Stroffolini T, Almasio P, Mele A, Coppola N, Ferrigno L, Scolastico C, Onofrio M, Imparato M, Filippini P. Exposure to HAV infection in patients with chronic liver disease in Italy, a multicentre study. J Viral Hepat. 2006;13:67-71.

13. Singal AK. Hepatitis A vaccine is not required in adult patients with chronic liver disease in Saudi Arabia. Singapore Med J. 2009:50:442-443

14. Stroffolini T, Almasio PL, Di Stefano R, Andreone P, Di Gaetano G, Fattovich G, Gaeta GB, Morisco F, Smedile A, Tripi S, Zignego AL, Ferraro D, Mele A, Craxi A. Anti-hepatitis A virus seroprevalence and seroconversion in a cohort of patients with chronic viral hepatitis. Dig Liver Dis. 2002;34:656-659.

15. Bertino G, Ardiri AM, Bruno MC, Valenti M, Lerna D, Boemi PM, Interlandi D, Urso G, Fisichella A, Pulvirenti D, Neri S. HAV infection in patients with chronic hepatitis C. Clin Ter. 2007;158:223-225.

16. da Silva EF, Mazo DF, Oliveira CP, Medeiros RP, Carrilho FJ, Pessôa MG. HAV and HBV seroprevalence in 1,000 patients with chronic HCV infection in a Tertiary Care Center in São Paulo, Brazil. Annals of Hepatology. 2016:15:691-695

17. Mattos AA, Gomes EB, Tovo CV, Alexandre CO, Remião JO. Hepatitis $B$ vaccine efficacy in patients with chronic liver disease by hepatitis C virus. Arq Gastroenterol. 2004;41:180-184.

18. Crockett SD, Keeffe EB. Natural history and treatment of hepatitis $B$ virus and hepatitis $C$ virus coinfection. Ann Clin Microbiol Antimicrob. 2005;4:13

19. Lee LP, Dai CY, Chuang WL, Chang WY, Hou NJ, Hsieh MY, Lin ZY, Chen SC, Hsieh MY, Wang LY, Chen TJ, Yu ML. Comparison of liver histopathology between chronic hepatitis $\mathrm{C}$ patients and chronic hepatitis B and C-coinfected patients. J Gastroenterol Hepatol. 2007;22:515-517.

20. Gltyson, JR Kramer, Z Duan, JA Davila. Prevalence and predictors of hepatitis B virus coinfection in a United States cohort of hepatitis C virus-infected patients. Hepatology. 2013;58:538-545.

21. Aygen B, Celen Mk, Koksal I, Tosun S, Karabay O, Yamazhan T, Yıldız O, Ayaz C, Tabak F. The prevalence and epidemiological characteristics of hepatitis $B$ virus and hepatitis $C$ virus coinfection in Turkey. Turkiye Klinikleri J Med Sci. 2013;33:1245-1249.

22. Demirtürk N, Demirdal T, Altındiș M, Așcı Z. Hepatitis B and hepatitis A virus serologies in patients infected with $\mathrm{HCV}$. Ege $J$ Med. 2007:46;97-100.

23. Akça F, Akca SD, Aydemir S,Aktunç E. The frequency of hepatitis $B$ virus infection in patients chronically infected with hepatitis $C$ virus: a retrospective study. TAHUD. 2012;16:3-7.

24. Yılmaz-Karadağ F. Investigation of Hepatitis B virus seroprevalence in Hepatitis C infected patients. Turk Hij Den Biyol Derg. $2017 ; 74: 287-292$

25. Karaca Ç, Çakaloğlu Y, Demir K, Özdil S, Kaymakoğlu S, Badur S ve ark. The frequency of hepatitis B Virus in patients with hepatitis $C$ virus. Akademik Gastroenteroloji Dergisi. 2004;3:76-78.

26. Ben Ayed M, Triki H, Cointe D, Karray H, Masmoudi MA, Dellagi $\mathrm{K}$, Grangeot L, Hammami A, Masmoudi $\mathrm{H}$. The isolated presence of anti- HBc antibodies: Prevalence and interpretation based on the results of viral DNA research and anti-HBs antibodies measurement after vaccination. Ann Biol Clin. 2001;59:53-60.

27. Neifer S, Molz B, Sucker U, Kreuzpaintner E, Weinberger K, Jilg W. High percentage of isolated anti-HBc positive persons among prisoners. Gesundheitswesen. 1997;59:409-402

28. Tahmaz A, Alkan Ceviker S, Günal Ö, Sırrı Kılıç S. Evaluation of Isolated Hepatitis B Core Antibody (Anti-Hbc lgg) Seropositivity in Chronic Hepatitis C Infected Patients. KSU Medical Journal. 2019;14:119-123 